Rendi Prayuda, Cifebrima Suyastri, Dhani Akbar| Kejahatan Transnasional

Terorganisir di Wilayah Perbatasan: Studi Modus Operandi Penyelundupan

Narkotika Riau dan Malaysia

Article

Kejahatan Transnasional Terorganisir di Wilayah Perbatasan: Studi Modus Operandi Penyelundupan Narkotika Riau dan Malaysia

Rendi Prayuda ${ }^{1}$, Cifebrima Suyastri ${ }^{2}$, Dhani Akbar $^{3}$

${ }^{1,2}$ Ilmu Hubungan Internasional,Universitas Islam Riau, Indonesia

${ }^{3}$ Ilmu Hubungan Internasional, Universitas Maritim Raja Ali Haji, Indonesia

\section{SUBMISSION TRACK}

$\begin{array}{ll}\text { Recieved } & : \text { 20 November } 2019 \\ \text { Final Revision } & : \text { 25 April } 2020 \\ \text { Available Online } & : \text { 30 May } 2020\end{array}$

KEYWORD

crime, transnational, narcotics and southeast asia

KATA KUNCI

kejahatan, transnasional, narkotika dan Asia Tenggara

CORRESSPONDENCE

E-mail : rendi_yuda@yahoo.com

\section{A B S T R A C T}

The Southeast Asian region has an area of around 4.4 million KM2 and is known as the "Golden Triangle" narcotics production area on the border of Thailand, Laos, and Myanmar. One of the destination countries for smuggling narcotics in the Southeast Asian region is Indonesia and Riau Province is one of the gateways for the illegal entry of narcotics from other countries, especially Malaysia. This paper aims to analyze the modus operandi of transnational crime in narcotics smuggling in the border regions of Riau and Malaysia. This paper uses a qualitative method using interviews with research informants. The results of this study indicate that the modus operandi of narcotics smuggling in the border regions of Indonesia and Malaysia is carried out by sea along the coastline of the border provinces of Riau and Malaysia. Narcotics are neatly wrapped and installed GPS devices then smuggled at night by using the services of fishermen as a courier. This seawater smuggling route was chosen due to several factors, namely: the proximity of the territorial waters, the number of unofficial or illegal ports, the lack of surveillance patrols along the water area and the professionalism of law enforcement officers in the border region.

\section{A B S T R A K}

Kawasan Asia Tenggara memiliki luas area sekitar 4,4 juta KM2 dan dikenal sebagai wilayah produksi narkotika "Golden Triangle" yang berada di perbatasan Thailand, Laos dan Myanmar. Salah satu negara tujuan penyelundupan narkotika di kawasan Asia Tenggara adalah Indonesia dan Provinsi Riau merupakan salah satu pintu gerbang masuknya narkotika secara ilegal dari negara lain terutama Malaysia. Tulisan ini bertujuan untuk menganalisis modus operandi kejahatan transnasional penyelundupan narkotika di wilayah perbatasan Riau dan Malaysia. Tulisan ini menggunakan metode kualitatif dengan menggunakan wawancara kepada informan penelitian. Hasil penelitian ini menunjukkan bahwa modus operandi penyelundupan narkotika di wilayah perbatasan Indonesia dan Malaysia dilakukan dengan menggunakan jalur laut disepanjang garis Pantai perbatasan Provinsi Riau dan Malaysia. Narkotika dibungkus rapi dan dipasang alat GPS selanjutnya diselundupkan pada malam hari dengan memanfaatkan jasa nelayan sebagai kurir. Jalur penyelundupan perairan laut ini dipilih dikarenakan beberapa faktor yaitu: jarak wilayah perairan yang dekat, banyaknya pelabuhan tidak resmi atau ilegal, minimnya patroli pengawasan di sepanjang wilayah perairan serta faktor profesionalitas aparat penegak hukum di wilayah perbatasan. 
Rendi Prayuda, Cifebrima Suyastri, Dhani Akbar | Kejahatan Transnasional

Terorganisir di Wilayah Perbatasan: Studi Modus Operandi Penyelundupan

Narkotika Riau dan Malaysia

\section{Pendahuluan}

Artikel ini merupakan sebuah tulisan yang mendeskripsikan mengenai dinamika terkait kejahatan transnasional pada kawasan Asia Tenggara terutama sebuah studi tentang modus operandi penyeludupan narkoba yang terjadi di Kawasan Asia terkhusus pada Provinsi Riau tepatnya di perbatasan Malaysia dan Indonesia. serta juga akan menganalisis bagaimana cara penyelundupan narkotika dilakukan oleh mafia kartel narkotika serta mengapa jalur tersebut digunakan sebagai jalur penyelundupan narkotika di wilayah Provinsi Riau perbatasan Indonesia dan Malaysia.

Pembagian klaster atau kategori wilayah Produksi, Distribusi dan Konsumsi pada jaringan pengedar atau penyelundupan obat-obat terlarang dan narkotika internasional di kawasan Asia Tenggara dikenal dengan nama kawasan Golden Triangle atau disebut dengan Segitiga Emas. Kawasan tersebut terletak pada perbatasan Laos, Thailand and Myanmar dan telah menghasilkan sekitar $60 \%$ hasil murni opium serta heroin di dunia. Narkotika yang di produksi pada kawasan ini telah mencapai puncak dan termasuk dalam potential addictive sebab terdapat beberapa jenis tumbuhan paparver somniferum dan poppy yang dapat menghasilkan heroin. Kawasan Golden Triangle ini memberikan sumbangan pada industri heroin yang bernilai US\$ 160 Milyar pertahun. ${ }^{1}$ Berikut ini merupakan grafik yang merupakan penjelasan perkembangan pertumbuhan opium yang ada pada daerah segitiga emas / Golden Triangle merujuk pada laporan oleh UNODC, yakni:

${ }^{1}$ Othman, Zarina. 2004. Myanmar. Illicit Drugs Trafficking and Security Implication Jakarta. Akademika. HIm 33

\footnotetext{
2 Transnational crime in the 21st century. (2005, January 1). Handbook of Transnational Crime and Justice, 43-46. https://doi.org/10.4135/9781412976183
} 
Rendi Prayuda, Cifebrima Suyastri, Dhani Akbar | Kejahatan Transnasional

Terorganisir di Wilayah Perbatasan: Studi Modus Operandi Penyelundupan

Narkotika Riau dan Malaysia

Tabel: 1 Bisnis Penyelundupan Narkotika di kawasan Asia Tenggara

\begin{tabular}{|c|c|c|c|c|}
\hline \multirow{2}{*}{$\begin{array}{l}\text { Member } \\
\text { States of } \\
\text { ASEAN }\end{array}$} & \multicolumn{4}{|c|}{ Seizures type of Narcotics } \\
\hline & $\begin{array}{c}\text { Opium } \\
\text { Raw \& } \\
\text { Prepar } \\
\text { e }\end{array}$ & Heroin & $\begin{array}{l}\text { Canabis } \\
\text { Herb }\end{array}$ & ATS \\
\hline $\begin{array}{l}\text { Brunei } \\
\text { Darussal } \\
\text { am }\end{array}$ & - & $\begin{array}{r}0,001 \\
\mathrm{~kg}\end{array}$ & $0,0054 \mathrm{~kg}$ & $1.648 \mathrm{~kg}$ \\
\hline $\begin{array}{l}\text { Cambodi } \\
\text { a }\end{array}$ & - & - & - & 50.565 units \\
\hline $\begin{array}{l}\text { Indonesi } \\
\text { a }\end{array}$ & $\begin{array}{r}0,034 \\
\mathrm{~kg}\end{array}$ & $\begin{array}{r}22.655 \\
\mathrm{~kg}\end{array}$ & $\begin{array}{r}6.332 .908 \\
\mathrm{~kg}\end{array}$ & $88.163 \mathrm{~kg}$ \\
\hline Lao PDR & $151 \mathrm{~kg}$ & $29 \mathrm{~kg}$ & $\begin{array}{r}18.734 .00 \\
0 \mathrm{~kg} \\
\end{array}$ & $\begin{array}{r}1.9577 .929 \\
\mathrm{~kg}\end{array}$ \\
\hline Malaysia & $0,71 \mathrm{~kg}$ & $\begin{array}{r}109.17 \\
\mathrm{~kg}\end{array}$ & $\begin{array}{r}1.885,45 \\
\mathrm{~kg} \\
\end{array}$ & $208,1 \mathrm{~kg}$ \\
\hline $\begin{array}{l}\text { Myanma } \\
\mathrm{r}\end{array}$ & $\begin{array}{r}1.7773 . \\
652 \mathrm{~kg}\end{array}$ & $\begin{array}{r}321.19 \\
3 \mathrm{~kg}\end{array}$ & $\begin{array}{r}601.508 \\
\mathrm{~kg}\end{array}$ & $\begin{array}{r}8.324 \mathrm{~kg} \mathrm{\&} \\
28.765,92 \\
\text { units }\end{array}$ \\
\hline $\begin{array}{l}\text { Philipine } \\
\text { s }\end{array}$ & - & $\begin{array}{r}0,022 \\
\mathrm{~kg}\end{array}$ & $\begin{array}{r}1.429 .474 \\
\mathrm{~kg}\end{array}$ & $\begin{array}{r}989,76 \mathrm{~kg} \\
\& \\
30 \text { units }\end{array}$ \\
\hline $\begin{array}{l}\text { Singapor } \\
\mathrm{e}\end{array}$ & $\begin{array}{r}4.504 \\
\mathrm{~kg}\end{array}$ & $\begin{array}{r}52.083 \\
\mathrm{~kg}\end{array}$ & $23.903 \mathrm{~kg}$ & $\begin{array}{r}0,759 \mathrm{~kg} \& \\
24.723 \text { units }\end{array}$ \\
\hline Thailand & $\begin{array}{r}1.591 .9 \\
91 \mathrm{~kg}\end{array}$ & $384 \mathrm{~kg}$ & $10.320 \mathrm{~kg}$ & $\begin{array}{r}7.557 \mathrm{~kg} \mathrm{\&} \\
84.000 .000 \\
\text { units }\end{array}$ \\
\hline Vietnam & $567 \mathrm{~kg}$ & $60 \mathrm{~kg}$ & $2.200 \mathrm{~kg}$ & 30.876 units \\
\hline
\end{tabular}

Sumber: ASEAN Narco Centre. Tahun 2016.

Berdasarkan data di atas, maka wilayah Asia Tenggara merupakan salah satu wilayah di Benua Asia yang memiliki perkembangan peredaran narkotika yang cukup besar selain di wilayah Asia Tengah. Hal ini dikarenakan bahan narkotika yaitu opium ditemukan ladangnya sebagian besar di wilayah GT/Segitiga Emas diantara perbatasan Thailand, Myanmar dan juga laos. Oleh karena itu, jika dianalisa terkait pendistribusian dan peredaran serta penyelundupan illegal narkotika di Asia Tenggara, maka bagi beberapa negara anggota ASEAN seperti Myanmar dan Laos maka bagi masyarakat setempat tanaman opium dipercaya sebagai tanaman obat sehingga masyarakat tradisional di tiga negara tersebut menaman tanaman opium secara massal dan faktor lainnya adalah faktor kemiskinan yang mengakibatkan para petani opium tersebut menjual opium tersebut kepada kartel narkoba dan diproduksi sebagai bahan dasar pembuat narkotika.
Dalam hal ini Indonesia menjadi salah satu negara di Kawasan Asia Tenggara yang menjadi tujuan penyelundupan illegal narkotika. Mewabahnya perdagangan illegal pada aspek narkotika dan persebarannya di Indonesia ini dikarenakan oleh narkotika di Indonesia ini disebabkan oleh dua faktor, yakni; (1) adanya permintaan dari konsumen yang artinya terdapat kebutuhan terhadap pasokan atau cadangan narkotika impor. (2) Kawasan di Indonesia terkenal sebagai wilayah yang memiliki kondisi geografis yang tentunya strategis sehingga Indonesia dapat dianggap mempunyai lahan yang berpotensi untuk perdagangan narkotika. Indonesia dengan bentuk archipelago yang terpisah-pisah antara pulau satu dan yang lainnya, kendati demikian pulau tersebut memiliki Sepuluh Titik Rawan dengan keamanan yang lemah sehingga memudahkan sindikat kejahatan pengedar narkotika untuk mengekspor narkotika tersebut ke wilayah Indonesia. Berdasar atas data resmi yang ditegaskan oleh Polri/ Kepolisian RI bahwasanya kasus obat terlarang dan narkotika di Indonesia terus meningkat sejak sekitar tahun 2010 yakni sekisaran 26.614 kasus, 2011 terdapat 26.500 kasus, selanjutnya di tahun 2012 pelonjakan kasus nerkotika tidak terlalu signifikan dibanding dengan tahun-tahun sebelumnya yakni hanya sekitar 0,23 persen, kemudian kembali bertambah sebanyak 61 kasus sehingga menjadi 26.561 kasus. Terakhir, di tahun 2013 kasus narkotika dan obat-obat illegal kembali melonjak signifikan yaitu sekitar 32.470 kasus hingga 2015 dapat dikalkulasikan dengan total kasus menjadi sekitar 44.321 kasus narkotika. ${ }^{3}$

Menurut informasi dan data dari Badan Narkotika Nasional atau BNN, Indonesia termasuk dalam negara

${ }^{3}$ http://www.asean.org/news/asean-secretariatnews/item/asean-reaffirmed comitment towardsdrug-free-vision 
berperigkat tertinggi dalam hal pengedaran narkotika secara massif di Asia Tenggara. Oleh sebab itu, tak heran bahwasannya beberapa kota-kota besar di Indonesia seperti Medan, Bali, Jakarta, Surabaya, Batam dan Pekanbaru menurut Mabes Polri merupakan kota yang tingkat penyebaran nya cukup tinggi dan terpusat. Selain itu, rute yang di gunakan para gembong narkotika illegal untuk mengedarkan narkotika di Indonesia ialah dengan melalui Jalur Perairan Perbatasaan Malaysia dan Prov. Riau yang termasuk salah satu rute dan gerbang keluar-masuknya narkotika illegal tersebut.

Riau Province atau Provinsi Riau menjadi kajian lokus dalam penelitian ini dikarenakan sampai dengan saat ini masih sangat minim kajian - kajian mengenai transnational crime di Kawasan Provinsi Riau terlebih pada masalah penyelundupan narkoba dan obat-obat terlarang illegal. Selain itu, letak kawasan ini yang langsung bersebrangan dan berbatasan dengan wilayah perairan Selat malaka, Malaysia, selain itu pula, terdapat tingginya intensitas aktivitas transnasional di wilayah Riau dan Malaka mengakibatkan meningkatnya intensitas perekonomian masyarakat di wilayah perbatasan. Akan tetapi perkembangan perekonomian di wilayah perbatasan ini disisi lain juga berdampak pada munculnya kegiatan - kegiatan ekonomi ilegal yang ada pada kawasan perbatasan Malaysia dan Provinsi Riau. Kegiatan yangmenjadi salah satu potensi menciptakan bentuk ancaman adalah kejahatan penyelundupan narkotika yang bersifat transnasional terutama apabila dilihat dari beberapa jenis sabu yang memang dikirim langsung secara illegal melalui jalur perabuhan yang non-resmi di kawasan Prov. Riau ini.

Permasalahan penyelundupan narkotika di kawasan Asia Tenggara merupakan ancaman keamanan secara regional artinya setiap warga negara di kawasan Asia Tenggara menjadi korban dalam penyalahgunaan narkotika secara ilegal dan masif. Wilayah Provinsi Riau yang berbatasan langsung dengan Malaysia di perairan Selat Malaka menjadikan Riau sebagai salah satu gerbang pintu masuk narkotika melalui jalur perairan (laut) sehingga mengakibatkan ancaman terhadap keamanan kemanusiaan menjadi sangat serius. Argumen ini dianalisis dengan menggunakan perspektif konstruktivisme yang fokus pada bagaimana aksi penyelundupan narkotika pada kawasan Asia Tenggara tepatnya di Wilayah Provinsi Riau perbatasan Malaysia dan Indonesia dilakukan serta mengapa bentuk modus operandi tersebut digunakan oleh para pelaku kejahatan narkotika di kawasan Asia Tenggara.

Artikel ini menggunakan perspektif konstruktivisme dalam menganalisis kejahatan transnasional di wilayah perbatasan khususnya modus operandi penyelundupan narkotika di kawasan Asia Tenggara studi kasus di wilayah Provinsi Riau perbatasan Indonesia dan Malaysia. Beberapa asumsi dasar dari perspektif konstruktivisme bahwa Negara tidak menjadi satu - satunya aktor dalam politik internasional, terdapat aktor lain dalam hubungan internasional seperti organisasi internasional, individu dan kelompok, isu keamanan dalam hubungan internasional tidak hanya perang dan militer, akan tetapi terdapat isu keamanan yang bersifat non militer seperti kejahatan transnasional terorganisir serta pengetahuan dan pemahaman bersama merupakan hasil kontruksi ide gagasan oleh interaksi di antara banyak aktor. ${ }^{4}$

'transnational organize crime' merupakan Istilah yang selalu dikaitkan dengan konteks golbalisasi ini seringkali

\footnotetext{
${ }^{4}$ Hermawan, Yulius. 2007. Transformasi Isu dan Aktor di dalam Studi Hubungan Internasional: dari Realisme hingga Konstruktivisme”. Yogyakarta: Graha Ilmu.
} 
diperkenalkan untuk menjabarkan ancaman kompleks antara kejahatan terorganisasi, white-collar crime dan korupsi yang muncul karena doktrin "kejahatan sebagai bisnis". Selain itu, pengaturan aktivitas kejahatan ini berdampak pada pelanggaran hukum domestik negaa yang dihasilkan oleh karakteristik ancaman membahayakan dari oknum dan sindikat kejahatan yang begulat pada level global. $^{5}$ Pada perkembangannya, pengkaitan dengan konsteks globalisasi dikarenakan adanya representasi terkait kondisi sosial-ekonomi, serta budaya dewasa ini. Maka sebab itu, perdebatan yang muncul dan sering terjadi terpusat pada peluang untuk melakukan berbagai upaya tindak criminal atau iligel yang tidak sah menurut dunia dalam peremangannya saat ini. Beragam pelaku tindak criminal umumnya di definisikan sebagai jaringan atau kelompok transnasional yang dalam kata lain merupakan transnational organized groups, transnational networks, dan transnational organization.

Berdasarkan pandangan dari Albanse, bahwa pertumbuhan kejahatan terorganisir yang terjadi di beerbagai negara tidak akan terlepas dari faktor penunjang pertumbuhan kejahatan itu sendiri. Ada 5 (lima) faktor pendukung/penunjang yakni seperti; (1) Regulasi Pemerintah baik domestic maupun global; (2) Ekonomi; (3) Tingkat Need dan permintaan konsumen; (4) Pembentukan pasar untuk mempromosikan barang/jasa dalam lingkungan sosial; (5) Teknologi dan lingkungan sosial. $^{6}$ Oleh sebab itu, kejahatan transnasional yang di lakukan

\footnotetext{
${ }^{5}$ L. Tobing, Fredy B. Aktifitas Drugs Trafficking Sebagai Isu Keamanan yang Mengancam Stabilitas Negara, dalam Jurnal Politik Internasional, Vol 5 No 1 November 2002.

${ }^{6}$ http://www.asean.org/communities/asean-politicalsecurity-community/item/asean-declaration-ontransnational-crime-manila-20-december-1997
}

secara berkelompok dan berorganisir disebut dengan TOC/ Transnational Organized Crime. Umumnya, perumusan tindak kejahatan dapat berlaku bagi tindak kejahtan transnasional ini dengan bentuk "Penyediaan barang atau jasa secara illegal demi mendapatkan keuntungan". Kejahatan yang bersifat terorganisasi ini merupakan salah satu betuk ancaman bagi national security suatu negara lantara berorientasi untuk mendapatkan power (Kekuasaan) atau Money (Uang).

Transformasi isu keamanan dalam kajian hubungan internasional memberikan dampak pada polarisasi hubungan antar negara yang mengakibatkan timbulnya sekuritisasi atau isu terkait keamanan nontradisional dalam perspektif dan paradigm keamanan lintas-batas negara atau internasional. Dalam hal ini kejahatan transnasional dilihat dalam aktivitasnya seperti kejahatan peniupan asuransi, pencucian uang, cyber crime, aktifitas terorisme, peredaran senjata perdagangan manusia,jual beli organ tubuh manusia, pencurian terkait benda cultural art, pembajakan laut, aktifitas pencurian intellectual resource, dan perdagangan narkotika serta obat-obatan terlarang lainnya ${ }^{7}$ Aktivitas kejahatan transnasional ini dapat teridentikasi oleh perdagangan narkotika itu sendiri lantaran sangat menguntungkan sehingga mampu memberi peluang untuk sindikat/ pelaku kejahatan mengulangi pengedaran narkotika tersebut secara massif. Tipe kejahatan penyelundupan narkotika dilakukan oleh para pelaku kejahatan yang terorganisir dengan jaringan kerja yang sangat rapi. ${ }^{8}$

Penelitian tentang fenomena kejahatan transnasional terorganisir ini

\footnotetext{
7 http//www.UNODC.org. 2015. Report of the Years. Publisher.

${ }^{8}$ Karns, Margaret P. \& Mingst, Karen A. 2004. The Search of Peace and Security. Dalam International Organizations: The Politics and Process of Global Governance. London: Lynne Riener Publisher, Inc.
} 
sudah dilakukan oleh beberapa peneliti yang menjelaskan dalam tulisannya terkait narkotika tersebut seperti Vignette dalam tulisan yang berjudul "International Drugs Trafficking, Organized Crime, And Terrorism In Afghanistan". Dalam tulisannya itu, ia mengemukakan bahwa perkembangand kejahatan transnational terkait narkotika di Afghanistan di dorong dan dipengaruhi oleh dua faktor yakni, (1) Faktor Geografis, akibat Afghanistan di apit dua lembah bernama Wakhan Corridor yang langsung berbatasan dengan Cina, sedangkan The Pamir Knotyang berhubungan dengan India, tepatnya di Himalaya. (2) Faktor Ekonomi, dimana sebagai negara yang terdapat potensi lahan pertambangan tumbuhan narkotika, Afghanistan memiliki lahan Poppy yaitu tumbuhan jenis opium yang apabila dip roses akan membentuk heroin dan jelas akan dilegalkan pemerintah. ${ }^{9}$ kemudian dijelaskan terdapat provinsi di Afghanistan yang bernama Prov. Helmand yang merupakan daerah khusus memproduksi massal opium terbesar hingga mampu melampaui Myanmar pada produksi opium di Burma.

Selanjutnya, Carl Troccki melakukan penelitian tentang penyalahgunaan drugs yang berjudul The Criminalization of Drugs. Drugs Before They Were Criminalizedmenjelaskan bahwa kriminalisasi narkotika adalah pelarangan terhadap segala bentuk kegiatan yang berhubungan dengan narkotika mulai dari kegiatan produksi, ekstraksi, perdagangan dan pemasaran. ${ }^{10}$ Sejak tahun 1725 Opium merupakan bentuk narkotika yang ilegal menurut Amerika Serikat, sedangkan bagi

9 M. P. McCarthy Dennis. 2001. An Economic History of Organized CrimeA national and transnational approach. New York. Routledge. Hlm 21

${ }^{10}$ C. A. Trocki. 1999. Opium, empire and the global political economy: A study of the Asian opium trade. New York: Routledge. negara sekutu Uni Soviet seperti Burma, Vietnam, Nicaragua dan Afghanistan perdagangan opium merupakan sumber devisa negara. Sebagai kejahatan transnasional maka perdagangan narkotika sangat menguntungkan, sehingga pelarangan terhadap peredaran dan perdagangan narkotika ini semakin mendorong terjadinya kejahatan transnasional perdagangan narkotika illegal. $^{11}$

Menurut tulisan Fransisco E. Thoumi dalam tulisannya yang berjudul The Impact of The Illegal Drug Industry On Colombia, ia menemukan bahwa perubahan dalam ekonomi dan politik secara global mengakibatkan tindak kejahatan di wilayah perbatasan negara. $^{12}$ Pada tahun 1990, pelaku perdagangan narkotika dari Kolombia menggunakan kapal, pesawat kargo untuk mengirim kokain di Pasar internasional. Rute ekspor dikembangkan secara ekstrim koordinasi yang kompleks melalui jalur udara dan laut untuk menembus negara transit. Pada tahun 1990 peredaran narkotika dilakukan dengan model perusahaan narkotika multinasional yang terstruktur diberbagai negara lengkap dengan pihak subkontraktor dan pekerja lepasnya serta dengan cara kerja penyelundupan, pemasaran, pencucian uang. Selanjutnya, tulisan elfira mengenai mengenai Eksistensi lembaga regional dalam menangani kejahatan narkotika, menghasilkan kesimpulan bahwa eksistensi lembaga regional dilakukan dengan menyepakati kerjasama masing - masing negara anggota melalui koordinasi penanganan dan pola penanganan masing masing negara dalam menyelesaikan

\footnotetext{
11 Edwards Adam and Peter Gill. 2003. Transnational OrganisedCrime Perspectives on global security London. Routledge.

12 Naylor, "From Cold War to Crime War: The Search for a New National SecurityThreat," Transnational Organized Crime1, no. 4 (Winter) 1995.
} 
masalah narkotika serta menjadikan kesepakatan bersama terutama dalam kebijakan masing - masing negara yang terintegrasi. ${ }^{13}$

Berdasarkan studi terdahulu diatas, maka beberapa tulisan yang terkait kejahatan tranansional narkotika lebih fokus pada permasalahan peredaran narkotika di sebuah negara serta bagaimana bentuk kebijakan dan diplomasi yang dilakukan oleh negara dalam mengantisipasi penyelundupan narkotika. Oleh karena itu tulisan ini fokus pada modus operandi kejahatan transnasional penyelundupan narkotika terorganisir di kawasan perbatasan Malaysia dengan Indonesia khusunya di wilayah Provinsi Riau dan Malaysia. Konsep pendekatan yang digunakan adalah terkait modus operandinya dalam kejahtan transnasional terorganissir terkait penyelundupan narkotika sehingga memudahkan peneliti untuk menganalisis bentuk modus operandi penyelundupan narkotika dan alasan rasional menggunakan jalur perbatasan Riau Malaysia sebagai jalur penyelundupan narkotika illegal.

\section{Metode Penelitian}

Metode penelitian yang diterapkan dalam tulisan ini adalah dengan metode kualitatif. Kendati demikian, penulis juga menggunakan beberapa sumber data yang bersifat kuantitatif seperti diagram, tabel statistik dan grafik dimana data tersebut digunakan untuk menjelaskan terkait skala angka dalam fenomena yang terjadi secara empiris. Jenis penelitian ini merupakan case study dimana dilakukan dengan metode kualitatif deskriptif dengan data yang berasar dari library research (studi

13 Fabira, Elfira. Upaya ASEAN dalam Menanggulangi Perdagangan dan Peredaran Narkotika Ilegal di Kawasan Asia Tenggara (20092012). Jurnal Ilmu Hubungan Internasional Unmul.org. No 2 Vol 3 tahun 2014. kepustakaan) dan field study (penelitian lapangan). ${ }^{14}$ Agar mendapat penjelasan yang komprehensif maka tulisan ini menggunakan pembagian jenis data yaitu data primer dan data sekunder. Data primer merupakan data yang penulis temukan saat berada dalam penelitian lapangan dimana bentuk data yang digunakan adalah interview atau wawancara dengan Sekretariat ASEAN di Jakarta (ASEANNARCO), dan Badan Narkotika Nasional Direktorat Reserse dan Narkoba yang berlaku sebagai informan. Selanjutnya, data sekunder yaitu sumber data tambahan yang penulis peroleh melalui penelitian dari sumber lain yang telah ada misalnya seperti Buku dan jurnal "transnational crime activity”, Laporan ASEAN-NARCO, Laporan setnas ASEAN, laporan tahunan Direktorat Reserse Narkoba dan sumber lain yang dinilai dapat mendukung dan membantu penulis dalam penelitian ini. Teknik penelitian yang penulis gunakan dalam penelitian ini adalah dengan menggunakan teknik wawancara mendalam terhadap infroman penelitian yaitu Sekretariat Nasional Republik Indonesia, Sekretarian ASEAN di Jakarta, ASEANNARCO, Direktorat Jendral kerjasama ASEAN Kementrian Luar Negeri Republik Indonesia, BNN, Direktorat Reserse dan Narkoba, serta pelaku tindak criminal penyelundupan narkoba dan obat-obat terlarang.

Selanjutnya adalah melakukan studi dokumentasi dengan membaca dokumen yang memiliki korelasi terhadap aktifitas tindak criminal transnasional terorganisasi terkait pengedaran dan penyelundupan narkotika. Termasuk juga dokumen penelitian atas upaya yang dilakukan oleh ASEAN sebagai alternatif penanganan kasus penyelundupan narkotika di kawasan Asia Tenggara. Dokumen-dokumen

14 Moleong, Lexi J. 2000. Metode Penelitian Kualitatif. Bandung. Remaja Rosdakarya. 
Rendi Prayuda, Cifebrima Suyastri, Dhani Akbar | Kejahatan Transnasional

Terorganisir di Wilayah Perbatasan: Studi Modus Operandi Penyelundupan

Narkotika Riau dan Malaysia

tersebut dapat berbentuk jurnal, buku, makalah, artikel serta penelitian terdahulu yang memiliki korelasi langsung dnegan penelitian penulis saat ini.

Sub bagian yang tidak dapat terlepas dalam rangkaian tulisan penelitian adalah kerangka berfikir sehingga, kerangka berpikir yang terpaut dalam tulisan ini adalah mengenai rute/jalur penyelundupan narkotika di Kawasan Asia Tenggara (Studi Kasusu di Kawasan Prov. Riau perbatasan Malaysia-Indonesia), yakni sebagai berikut:

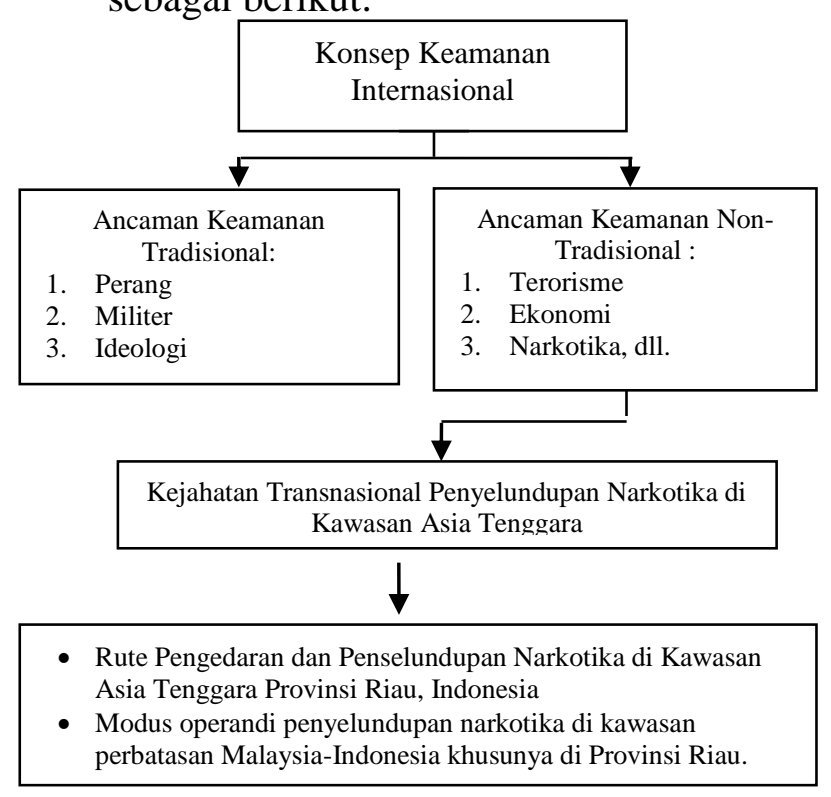

Gambar: 2 Kerangka Berpikir Penelitian

Sumber: Data Olahan Penelitian. Tahun 2019

\section{Hasil dan Pembahasan}

Merupakan salah satu bentuk ancaman yang rill saat ini bagi keamanan manusia yakni terkait dengan penyalahgunaan narkotika juga perdagangan gelap. Prevalensi Penyelewengan narkoba yang terjadi di dunia dimulai sejah tahun 2006-2018 mengalami lonjakan yang signifikan, meskipun dapat dilihat adanya kurva dengan jumlah keseluruhan yang tinggi, besaran prevalensi penyalahgunaan narkotika di dunia dapat di estimasi dengan kisaran 4,9 persen atau dalam satuan sekitar 208 juta penggunaan pada tahun 2006 kemudian mengalami penurunan di tahun 200-2009 yakni menjadi 4,6 persen dan 4,8 persen. Akan tetapi kembali meningkat menjadi sekitar 5,2 persen di tahun 2011 dan masih stabil hingga 2013. Maka secara absolute, diperkirakan hampir mendekati kisaran angka 167-315 juta jiwa orang yang melakukan penyalahgunaan narkotika dengan usia kisaran 15-64 tahun dengan minimal penggunaan 1 kali dalam setahun sejak 2013.

Pada 5 tahun terakhir tren narkotika jenis ekstasi terindikasi menurut sekita $15 \%$ di berbagai negara. Sementara penggunaan Amphetamin dilaporkan masih stabil. Kendati demikian, terdapat peningkatan drastic sekitar $158 \%$ dalam 5 tahun terakhir ini yaitu pengkonsumsi jenis metha amphetamine. Pada tahun 2014, narkoba jenis sintetis baru muncul dan berkembang dalam perdagangan ilegal. Perkembangan tersebut meningkat sekitar 1,5 kali dibanding 2009. Dalam kasusnya lebih dari 90 negara yang melaporkan kasus narkotika jenis baru ini setiap tahunnya.Narkoba jenis sintetis ini menjadi komoditas "legal highs" dan berhasil menggantikan narkoba jenis stimulant seperti ekstasi dan kokain. Maraknya, narkoba jenis sintetis ini sering di perjual belikan melalui internet atau secara daring karena banyak market-market online. Di sebagian besar negara pengggunaan ganja juga meningkat. Penyalahgunaan ganja juga menjadi momok tersendiri lantaran maraknya penggunaan yang memerlukan pengobatan khusus. Selain itu, penggunaan ATS terus meningkat secara global, hal ini terjadi lantaran ATS dapat digunakan sebagai obat dalam mengatasi ganggunan-gangguan penggunaan opiate. $^{16}$

15 ASEAN - Narcothics Cooperation Center. 2015. ASEAN Drug Monitorning Report. Thailand. ASEAN NARCO.

$16 \mathrm{http} /$ www.unodc.org. Illicit Drugs in World System. 
Rendi Prayuda, Cifebrima Suyastri, Dhani Akbar| Kejahatan Transnasional

Terorganisir di Wilayah Perbatasan: Studi Modus Operandi Penyelundupan

Narkotika Riau dan Malaysia

Setelah terjadinya perang dingin atau cold war pada 1990, Asia Tenggara tepatnya di Thailand dijadikan jalur masuknya perdagangan opium (Myanmar) dan Heroin (Perbatasan Laos). Melonjaknya produksi illegal methamphetamine Myanmar pada tahun 1990 saat itu diikuti dengan derasnya arus edaran narkotika di Thailand yang berasal pula dari Myanmar itu sendiri. Hingga saat ini, Thailand dikenal sebagai tempat di kawasan Asia tenggara dengan pengedar narkotika tertinggi. Sebab hampir semua jenis narkotika dan obat-obat terlarang diperjual belikan secara illegal disana. Berikut ini adalah data tabel dari penjelasan jenis opium yang ditemukan di Asia Tenggara, yakni sebagai berikut;

Tabel: 2 Tren Jenis Narkoba di Asia Tenggara

\begin{tabular}{|c|c|c|c|}
\hline \multirow{2}{*}{$\begin{array}{l}\text { Drug } \\
\text { Type }\end{array}$} & \multicolumn{3}{|l|}{ Trend in abuse } \\
\hline & Increase & Stable & Decrease \\
\hline $\begin{array}{l}\text { Methamp } \\
\text { etamine } \\
\text { pills }\end{array}$ & $\begin{array}{l}\text { Cambodia, Lao } \\
\text { PDR, Myanmar, } \\
\text { Vietnam }\end{array}$ & & Thailand \\
\hline $\begin{array}{l}\text { Methamp } \\
\text { etamine } \\
\text { crystal }\end{array}$ & $\begin{array}{l}\text { Cambodia, } \\
\text { Indonesia, Thailand }\end{array}$ & $\begin{array}{l}\text { Philippine } \\
\text { s }\end{array}$ & $\begin{array}{l}\text { Brunei, } \\
\text { Malaysia, } \\
\text { Singapore }\end{array}$ \\
\hline Ectasy & $\begin{array}{l}\text { Brunei, Indonsia, } \\
\text { Vietnam }\end{array}$ & Cambodia & $\begin{array}{l}\text { Malaysia, } \\
\text { Singapore, } \\
\text { Tailand }\end{array}$ \\
\hline Heroin & $\begin{array}{l}\text { Cambodia, } \\
\text { Indonesia, Lao, } \\
\text { Singapore, Vietnam }\end{array}$ & & $\begin{array}{l}\text { Malaysia, } \\
\text { Myanmar, } \\
\text { Thailand }\end{array}$ \\
\hline Opium & Singapore & & $\begin{array}{l}\text { Cambodia, } \\
\text { Lao, } \\
\text { Malaysia, } \\
\text { Myanmar, } \\
\text { Thailand, } \\
\text { Vietnam }\end{array}$ \\
\hline Cocaine & & Thailand & \\
\hline Cannabis & $\begin{array}{l}\text { Brunei, Philippines, } \\
\text { Singapore, Tailand }\end{array}$ & $\begin{array}{l}\text { Cambodia } \\
\text {, Lao }\end{array}$ & $\begin{array}{l}\text { Malaysia, } \\
\text { Thailand } \\
\text { (resin) }\end{array}$ \\
\hline Ketamine & & & $\begin{array}{l}\text { Singapore, } \\
\text { Thailand }\end{array}$ \\
\hline $\begin{array}{l}\text { barbiturat } \\
\text { es }\end{array}$ & Thailand & & \\
\hline $\begin{array}{l}\text { Benzondi } \\
\text { azepines }\end{array}$ & Thailand & & $\begin{array}{l}\text { Brunei, } \\
\text { myanmar, } \\
\text { singapore }\end{array}$ \\
\hline Inhalants & Thailand & Cambodia & Malaysia \\
\hline
\end{tabular}

Sumber: United Nations Office on Drugs and Crime (UNODC), Tahun 2016.

Berdasarkan data-data diatas setidaknya dapat memberi gambaran bahwa tingkat bahaya penyalahgunaan narkotika dan obat-obatan berbahaya di kawasan Asia Tenggara sudah pada tahap urgensi tiggi. Setiap negara ASEAN memiliki jenis narkoba tertentu disertai dengan jumlah tertentu. Mulai dari jenis narkoba yang masih berbahan mentah seperti opium mentah hingga jenis narkoba yang sudah dalam bentuk olahan seperti heroin maupun ATS (amphetamine) tersebar merata di masing-masing negara. ${ }^{17}$ Sejak tahun 2006 ini jenis-jenis narkoba semakin banyak hingga mengakibatkan tren nasional di setiap negara berubah seiring dengan tren konsumen. Berikut ini merupakan alur penyelundupan narkotika di kawasan Asia Tenggara, yaitu:

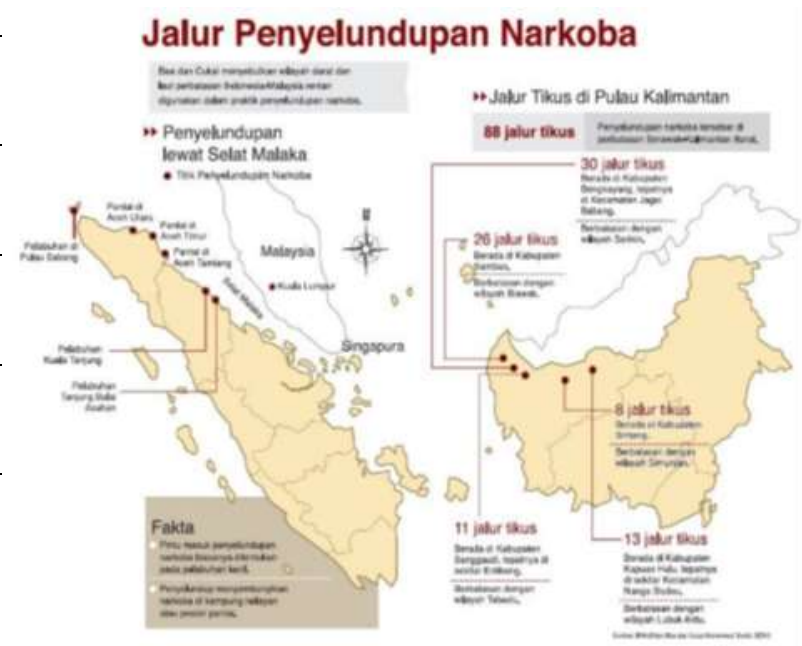

Gambar: 3 Jalur Penyelundupan Narkoba
Melalui Perbatasan Indonesia
Sumber: Media Indonesia (Utami, 2016)

Melalui penggambaran tersebut maka dapat dijelaskan bahwa aktivias dan proses masuknya narkotika dari Pelabuhan Malaysia menuju Indonesia dengan

17 Victor Muhammad, Simela. Diplomasi Anti Narkoba. Jurnal Hubungan Internasional. Kajian Singkat terhadap Isu Aktual dan Strategis. Vol. VII, No.05 / I / P 3DI/Maret 2015. 
menggunakan rute perbatasan transportasi baik darat maupun laut di Negara Indonesia. Dilihat dari gambar peta diatas, wilayah Nunukan dan Tawao, Kalimantan dijadikan sebagai rute penyelundupan narkotika di perbatasan darat. Setelah berhasil diselundupkan, narkoba tersebut akan disebarkan menuju kota-kota besar di daerah timur dan tengah Indonesia. Sementara di wilayah perairan/laut Provinsi Riau dan Provinsi Kepulauan Riau dinobatkan menjadi jalur penyelundupan narkotika dari rute Malaysia menuju Indonesia.

\section{Jalur Penyelundupan Narkotika di Perbatasan Malaysia dan Provinsi Riau, Indonesia.}

Apabila ditelursuri dan dilihat secara geografis maka dapat dikatakan bahwa Prov. Riau memiliki potensi strategis lantaran berbatasan langsung dengan negara Singapura, Thailand, dan Malaysia. Sselain itu, Provinsi Riu berhadapan langsung dengan rute Perlintasan Perdagangan dunia yaitu selat malaka. Belum lagi bahwa kawasan regional Sumatera Provinsi Riau berada tepat dibagian tengah Pulau Sumatera yang memang merupakan tempat strategis pada lintasan pergerakan antar wilayah yang memberikan potensi untuk membangun akses tinggi bagi lalu lintas barang, jasa, orang, modal dan informasi. Provinsi Riau secara geografis berbatasan dengan wilayah, sebagai berikut :

- Timur: Provinsi Kepri (Kepulauan Riau)

- Barat: Provinsi Sumatera Utara.

- Selatan: Provinsi Jambi dan Sumatera Barat.

- Utara: Selat Malaka (Berbatasan Langsung Provinsi Riau dan Malaysia). ${ }^{18}$

\footnotetext{
${ }^{18}$ Direktorat Reserse dan Narkotika Kepolisian Negara Republik Indonesia Daerah Riau. 2017.
}

Provinsi riau apabila di jelaskan memiliki panjang garis pantai yang membentang luas dari Wilayah Panipahan Kab. Rokan Hilir hingga ke Wilayah Pulau Kijang Kab. Indragiri Hilir dengan kisaran panjang 370 mil atau setara dengan 685,24 km. Jumlah Pulau yang ada di Provinsi Riau berkisar sebanyak 139 pulau dengan rincian 73 pulau yang bernama dan 66 pulau tanpa nama. Selain itu, Provinsi Riau juga memiliki pulau dengan letak berapitan atau bersebrangan dengan Malaysia. Yaitu:

1. Tj. Parit yang berbatasan langsung dengan $\mathrm{Tj}$. Tohor Malaysia.

2. Pulau Sinaboi berbatasan dengan Port Dickson, Malaysia.

3. Tj. Medang berbatasan dengan $\mathrm{Tj}$. Rachado Malaysia.

4. Pulau Jemur yang hanya berjarak sekitar 45 mil atau 83,34 $\mathrm{km}$ dari Wilayah Batu Kuching Malaysia.

5. Tj. Kedabu berbatasan dengan Pulau Pisang.

6. Pulau Tokong Berbatasan dengan Batu Kuching Malaysia.

Dengan ini maka dapat dikatakan bahwa Provinsi Riau berbatasan langsung dibagian Utara dengan Selat Malaka dengan jarak hanya $83 \mathrm{~km}$ dari Batu Kuching Malaysia. Terdapat pula 3.214 pulau besar dan kecil yang tersebar secara strategis di daerah perairan. ${ }^{19}$ Dikarenakan memang rute di Selat Malaka dan Laut Cina Selatan dijadikan sebagai jalur lintas pelayaran utama dalam dunia perdagangan global. Akibat posisi yang dinilai sangat strategis ini, Provinsi Riau dijadikan sebagai salah satu gerbang masuknya pengedaran dan Penyelundupan narkotika di wilayah Asia Tenggara. Penyelundupan narkotika yang berhasil masuk ke Provinsi Riau melalui jalur laut atau perairan dari negara transit yaitu Malaysia. Terdapat

Paparan Kapolda Riau mengenai Kejahatan Transnasional Narkotika di Provinsi Riau. Pekanbaru. Seminar Nasional Universitas Riau.

${ }^{19}$ Ibid. Hlm 2 
beberapa faktor yang menjadi pendorong perkembangan bisnis narkotika illegal di kawasan Asia Tenggara terutama narkotika yang diselundupkan melalui pelabuhan di perbatasan Malaysia menuju Provinsi Riau, yaitu :

1. Perbedaan harga jual yang signifikan antara beberapa negara di kawasan Asia Tenggara.

2. Melonjaknya angkajobless atau pengangguran di beberapa kawasan di Asia Tenggara.

3. Tingkat dan kondisi kemiskinan menyebabkan peluang untuk dengan mudah merekrut kurir selain itu biaya prekrutan juga cukup murah.

4. Hasil menunjukkan jumlah pengguna atau pemakai narkotika di indonesia saat ini telah melebihi dari 5 juta orang. ${ }^{20}$

Berikut ini merupakan petarute masuknya narkotika dari malaysia menuju pelabuhan di sepanjang pesisir pantai di wilayah Provinsi Riau, yakni sebagai berikut :

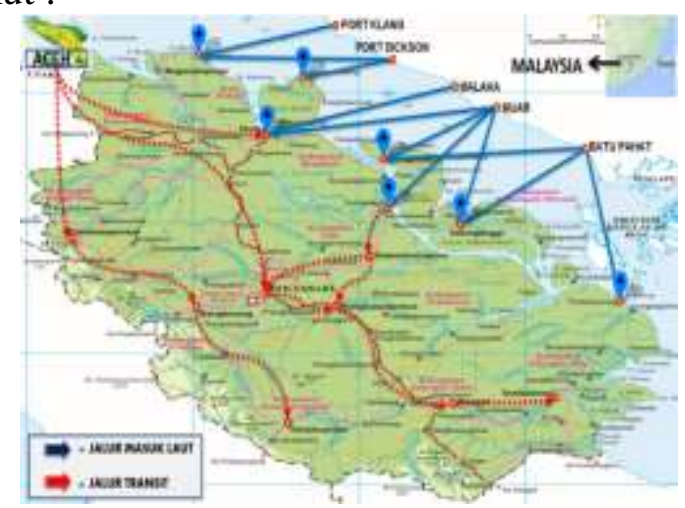

Gambar: 4 Peta Jalur Masuk Narkotika di Wilayah Provinsi Riau

Sumber: Direktorat Reserse Narkoba Kepolisian Negara Republik Indonesia Daerah Riau. Tahun 2017.

Berdasarkan peta diatas, maka terdapat lima Kabupaten/Kota di Provinsi Riau yang berbatasan langsung dengan

\footnotetext{
${ }^{20}$ Hasil wawancara penulis bersama Direktur Narkoba Polda Riau pada tanggal 21 Maret 2018
}

negara Malaysia seperti Kabupaten Rokan Hilir, Kota Dumai, Kabupaten Bengkalis, Kabupaten Kepulauan Meranti dan Kabupaten Indragiri Hilir. Rute jalur penyelundupan narkotika di wilayah Provinsi Riau perbatasan Indonesia dan Malaysia dikirim melalui negara produksi yaitu China dan Taiwan. Selanjutnya, narkotika yang dikirim melalui jalur transit Malaysia tersebut akan diselundupkan melalui pelabuhan - pelabuhan tidak resmi yang berada di sepanjang garis pantai Pulau Sumatera wilayah Provinsi Riau.

Beberapa rute penyelundupan narkotika yang dikirim dari negara Malaysia, masuk melalui wilayah pelabuhan Provinsi Riau dan siap dikirim ke beberapa Kota besar di Indonesia dapat dideskripsikan dalam penjelasan berikut ini bahwa pengiriman narkotika yang dikirim dari Malaysia tersebut diselundupkan melalui Pelabuhan Port Klang yang selanjutnya akan diselundupkan menuju pelabuhan di daerah Bagan Siapi-Api yaitu daerah Penipahan dan Pulau Jemur), Paket narkotika tersebut selanjutnya akan dikirim menuju Provinsi Sumut (Sumatra Utara) tak terkecuali Kota Medan. Untuk Wilayah Pelabuhan Port Disckson sendiri akan di selundupkan melalui perairan Kota Dumai dan Pulau Rupat sehingga selanjutnya paket berisi narkotika tersebut akan di kirim melalui Kabupaten Bengkalis menuju Kota Pekanbaru, Provinsi Riau.

Selanjutnya, pengiriman paket narkotika yang diselundupkan melalui Pelabuhan Malaka dan Muar akan di kirim menuju Perairan Bengkalis dan Siak melalui Pelabuhan Buton untuk dikirim ke Kota Pekanbaru dan Provinsi Jambi sedangkan narkotika yang diselundupkan dari Dermaga atau pelabuhan Malaysia tepatnya di Batu Pahat dan masuk menuju Pelabuhan Selatpanjang Kab. Kepulauan Meranti dan Tembilahan, Kab. Indragiri Hilir yang kemudian akan dikirim untuk konsumsi narkotika di Kota Padang, 
Bandar Lampung, Palembang serta DKI Jakarta. Maka dari itu, penyelundupan narkotika illegal yang berasal dari sindikat dengan skala global di Asia Tenggara ini merupakan motif kejahatan dengan berbasis rute strategis dan menguntungkan bagi para sindikat atau mafia penyelundupan narkotika illegal menuju ke wilayah/ kota besar di Indonesia.

Berdasar pada hasil observasi penulis dilapangan terhadap hasil dari pemetaan langsung rute penyelundupan narkotika khusunya di wilayah Provinsi Riau yang berasal dari negara Malaysia ini maka kegiatan penyelundupan narkotika tersebut dilakukan dengan cara yaitu; para bandar narkotika menyelundupkan narkotika pada saat malam hari dan memanfaatkan nelayan sebagai kurir narkotika. Narkotika yang diselundupkan oleh para bandar narkotika dari Malaysia tersebut dikirim oleh para kurir dari Malaysia dan transaksi narkotika tersebut dilakukan di tengah laut di wilayah perbatasan Indonesia seperti di wilayah perairan Rokan Hilir, Bengkalis, Indragiri Hilir dan Meranti yang selanjutnya akan dibawa oleh nelayan menuju daratan. Paket narkotika yang diselundupkan tersebut dibungkus plastik tebal sehingga tidak tembus air dan terkadang diberikan GPS sebagai pelacak sinyal.

Menurut Direktur Satuan Narkoba Polda Riau, bahwa setelah dilakukan transaksi ditengah laut pada saat malam hari maka paket narkotika yang dibawa oleh nelayan tersebut diletakkan diperahu nelayan ataupun terkadang diletakkan menggantung didalam laut dibawah kapal nelayan. Hal ini dilakukan untuk mengelabui patroli Satuan Polisi Perairan dan Patroli AL jika terjadi razia yang dilakukan oleh aparat. Tidak jarang jika tersudut akan pemeriksaan kapal oleh aparat petugas di wilayah perairan paket narkotika tersebut ditenggelamkan didasar laut dengan alat GPS dan setelah patroli wilayah perbatasan selesai maka nelayan tersebut akan kembali menyelam kedasar laut untuk melacak sinyal GPS dari paket narkotika yang telah ditenggelamkan tadi. Selanjutnya nelayan akan membawa paket narkotika tersebut ke daratan untuk selanjutnya di bawa oleh kurir daratan menuju daerah tujuan paket narkotika tersebut dikirimkan. ${ }^{21}$

Oleh karena itu, dapat dianalisis secara ringkas bahwa operasi illegal penyelundupan dan peredaran obat serta narkotika dari Negara Malaysia menuju Kawasan negara Indonesia khusunya di Provinsi Riau berdasarkan sumber dari Direktur Reserse Narkoba Polda Riau dalam modus operandinya juga dilakukan menggunakan transportasi laut yang dalam hal ini kapal menuju kedalam pelabuhan resmi namun dengan menyamarkan isi muatan kapal. Selain itu, juga terdapat motif penyelundupan dengan modus operandi lainnya seperti menelan narkotika di dalam perut, dimasukkan dalam kemasan makanan, di samarkan dalam Koper/Travel Bag atau memasukkan narkotika ke dalam anus. Selanjutnya modus yang sering terjadi adalah dengan menggunakan jasa pengiriman paket serta Ship to ship atau melalui pelayaran kapal.

Wilayah Provinsi Riau yang terdiri atas Kabupaten yang tepat beradai di daerah pesisir yakni Kota Dumai, Kab. Rokan Hilir, Kab. Indragiri Hilir, Kab. Bengkalis, Kab. Siak, serta Kab. Kepulauan Meranti yang menjadi nominasi sebagai wilayah gerbang masuknya penyelundupan narkotika illegal akibat beberapa faktor yakni (1) Penyelundupan ini terjadi dikarenakan hukum permintaan dan penawaran yang cukup tinggi. Artinya saat ini permintaan narkotika cukup tinggi di Indonesia. Bahkan Indonesia dan Provinsi Riau masuk dalam kategori lima besar yang memiliki rute peredaran narkotika secara massif setelah Medan, Jakarta, Sulawesi

${ }^{21}$ Ibid. 
Tenggara dan Surabaya. Maka dari itu besarnya permintaan terhadap narkotika dan keuntungan yang besar dari penjualan ini mengakibatkan wilayah Riau menjadi salah satu alternatif pilihan yang potensial dalam penyelundupan narkotika.

Selain faktor keuntungan bisnis ilegal, maka faktor kedekatan wilayah antara wilayah Provinsi Riau dengan Malaysia mengakibatkan jalur laut ataupun perairan menjadi alternatif yang sangat potensial untuk menyelundupkan narkotika. Hal ini dikarenakan jalur laut di wilayah Provinsi Riau masih sangat luas dan banyaknya pelabuhan - pelabuah rakyat atau ilegal di wilayah perbatasan Malaysia dan Provinsi Riau, Indonesia mengakibatkan para pelaku kejahatan dengan leluasa bisa menyelundupan narkotika melalui pelabuhan - pelabuhan tidak resmi tersebut. (2) Faktor selanjutnya adalah lemahnya regulasi dan penegakan hukum serta pengawalan kelembagaan pemerintah yang juga menjadi faktor mengapa bisnis-transaksi obat-obatan terlarang illegal di Kawasan Asia Tenggara terus berkembang. ${ }^{22}$ Oleh karena itu, minimnya patroli atau pengawasan secara rutin di wilayah perbasatan Riau dan Malaysia juga menjadi kendala dalam penanganan penyelundupan narkotika secara ilegal serta faktor profesionalitas aparat keamanan dalam pelaksanaan patroli rutin artinya menurut Direktur narkoba Polda Riau bahwa sampai dengan saat ini masih banyak anggota Polri yang terjerumus dalam bisnis narkotika secara ilegal dikarenakan tergiur atas keuntungan penjualan narkotika yang berlipat ganda.

\section{Kesimpulan}

Didasarkan pada penjelasan diatas, terkait penyelundupan narkotika maka dapat diambil simpulan bahwa Riau

\footnotetext{
${ }^{22}$ Mahbubany Kishore and Jeffery. 2017. ASEAN Miracle. Singapore. NUS Press. HIm 187
}

Province adalah pintu masuknya narkotika illegal serta perkumpulan Bandar tindak criminal terkait penyelundupan narkotika illegal ini. Penyelundupan narkotika ini dapat masuk melalui lintas laut terkhusus dengan penggunaan rute pelabuhan nonresmi mengikuti sepanjang garis pantai di Prov. Riau dengan rute transit dari negara Malaysia. Maka dari itu, rute penyelundupan narkoba tersebut berasal dari Malaysia menuju Indonesia dengan munggunakan rute khusus di kawasan Provinsi Riau dimana dilakukan dengan penggunaan jalur perairan atau transportasi laut dan masuk ke dermaga illegal. Sehingga narkotika yang masuk melalui pelabuhan sinaboi kab. Rokan Hilir akan di transfer atau di distribusikan menuju medan dan sekitarnya. Sedangkan nerkotika yang masuk melalui Pulau Rupat kab. Bengkalis bakal di distribusikan menuju wilayah kota Pekanbaru, kemudian Pulau Rangsang dan Tebing tinggi, trakhir masuk menuju pelabuhan sungai guntung kab. Rokan Hilir akan di kirim menuju wilayah Jambi, Palembang serta Pulau Jawa.

Rute ini dipilih para mafia kartel narkotika ini lantaran faktor geografis Provinsi Riau yang sangat dekat dengan Malaysia sehingga narkotika dengan cepat bisa diselundupkan, selain itu faktor banyaknya pelabuhan - pelanbuhan tidak resmi yang ada di sepanjang garis pantai pada wilayah perbatasan Malaysia dan Provinsi Riau sehingga para kurir narkotika bebas masuk tanpa pengawasan ketat dari petugas, faktor berikutnya adalah dualisme pekerjaan dari nelayan di wilayah perbatasan yang juga memiliki pekerjaan sebagai kurur narkotika dari tengah laut menuju darat. Faktor penegakaan hukum oleh aparat penegak hukum Indonesia juga menjadi faktor alasan Riau menjadi salah satu wilayah penyelundupan narkotika artinya minimnya patroli pengawasan rutin oleh petugas serta faktor profesionalitas petugas keamanan wilayah perbatasan juga 
Rendi Prayuda, Cifebrima Suyastri, Dhani Akbar | Kejahatan Transnasional Terorganisir di Wilayah Perbatasan: Studi Modus Operandi Penyelundupan Narkotika Riau dan Malaysia

menjadi salah satu faktor pendorong terjadinya peningkatan terhadap angka penyelundupan narkotika. Maka dari itu, jaringan kejahatan transnasional di perbatasan Malaysia dan Riau ini dibilang sangat terorganisisr dengan baik dan memiliki beberapa sindikat atau mata rantai sehingga dalam pelaksanaannya para sindikat tersebut memiliki satu perwakilan di tiap-tiap negara di kawasan anggota ASEAN.

\section{DAFTAR PUSTAKA}

ASEAN - Narcothics Cooperation Center. 2015. ASEAN Drug Monitorning Report. Thailand. ASEAN NARCO.

C. A. Trocki. 1999. Opium, empire and the global political economy: A study of the Asian opium trade. New York: Routledge.

Direktorat Reserse dan Narkotika Kepolisian Negara Republik Indonesia Daerah Riau. 2017. Paparan Kapolda Riau mengenai Kejahatan Transnasional Narkotika di Provinsi Riau. Pekanbaru. Seminar Nasional Universitas Riau.

Edwards Adam and Peter Gill. 2003. Transnational OrganisedCrime Perspectives on global security London. Routledge.

Fabira, Elfira. Upaya ASEAN dalam Menanggulangi Perdagangan dan Peredaran Narkotika Ilegal di Kawasan Asia Tenggara (2009-2012). Jurnal Ilmu Hubungan Internasional Unmul.org. No 2 Vol 3 tahun 2014.

Hermawan, Yulius. 2007. Transformasi Isu dan Aktor di dalam Studi Hubungan Internasional: dari Realisme hingga Konstruktivisme". Yogyakarta: Graha Ilmu.

http//www.UNODC.org. 2015. Report of the Years. Publisher.

http//www.unodc.org. Illicit Drugs in World System.

http://www.asean.org/communities/asean-political-security-community/item/aseandeclaration-on-transnational-crime-manila-20-december-1997

http://www.asean.org/news/asean-secretariat-news/item/asean-reaffirmed commitment towards-drug-free-vision

Karns, Margaret P. \& Mingst, Karen A. 2004. The Search of Peace and Security. Dalam International Organizations: The Politics and Process of Global Governance. London: Lynne Riener Publisher, Inc.

L. Tobing, Fredy B. Aktifitas Drugs Trafficking Sebagai Isu Keamanan yang Mengancam Stabilitas Negara, dalam Jurnal Politik Internasional, Vol 5 No 1 November 2002.

M. P. McCarthy Dennis. 2001. An Economic History of Organized CrimeA national and transnational approach. New York. Routledge.

Mahbubany Kishore and Jeffery. 2017. ASEAN Miracle. Singapore. NUS Press.

Moleong, Lexi J. 2000. Metode Penelitian Kualitatif. Bandung. Remaja Rosdakarya.

Othman, Zarina. 2004. Myanmar. Illicit Drugs Trafficking and Security Implication, Jakarta. Akademika.

Naylor, "From Cold War to Crime War: The Search for a New National SecurityThreat," Transnational Organized Crime1, no. 4 (Winter) 1995.

Transnational crime in the 21st century. (2005, January 1). Handbook of Transnational Crime and Justice, 43-46. https://doi.org/10.4135/9781412976183

Victor Muhammad, Simela. Diplomasi Anti Narkoba. Jurnal Hubungan Internasional. Kajian Singkat terhadap Isu Aktual dan Strategis. Vol. VII, No.05 / I / P 3DI/Maret 2015 
Rendi Prayuda, Cifebrima Suyastri, Dhani Akbar| Kejahatan Transnasional Terorganisir di Wilayah Perbatasan: Studi Modus Operandi Penyelundupan Narkotika Riau dan Malaysia 